\title{
Barite replacement boxwork in the Frasassi caves (Italy)
}

\author{
Sandro Galdenzi \\ 60035 Jesi, Italy
}

\begin{abstract}
The Frasassi caves, located in the Sentino River Gorge in Ancona Province (Marche, Italy), contains boxwork in a small zone in the inner part of the cave system where it is closely associated with subaqueous corrosion produced by sulfuric acid speleogenesis. The boxwork consists of barite that replaces calcite spar-filled veins and limestone porosity and projects from the corroded cave walls. The replacement involved only the calcite that protrudes from the rock surfaces, indicating that the process took place in the cave environment, and therefore the boxwork is not simply a product of differential corrosion. I hypothesize that the boxwork formed in nearly stagnant bodies of sulfidic water as a consequence of lateral recharge of $\mathrm{O}_{2}$-rich bicarbonate water moving upward along the walls because of its lower density. The acidity produced by the oxidation of $\mathrm{H}_{2} \mathrm{~S}$ enhanced limestone corrosion and incision of rills and channels, while also releasing sulfate ions that induced the precipitation of barite. This sulfuric acid process was sufficiently slow to dissolve the micritic bedrock and replace spar with barite, preserving the shape of the network of fissures and pores formerly filled by calcite.
\end{abstract}

Keywords: $\quad$ boxwork, karst, sulfuric acid speleogenesis, barite, Frasassi caves

Received 2 August 2019; Revised 23 August 2019; Accepted 28 August 2019

Citation: Galdenzi S., 2019. Barite replacement boxwork in the Frasassi caves (Italy). International Journal of Speleology, 48 (3), 305-310. Tampa, FL (USA) ISSN 0392-6672 https://doi.org/10.5038/1827-806X.48.3.2223

\section{INTRODUCTION}

Boxwork is a solutional cave feature consisting of thin veins that protrude from bedrock walls, speleothems and clay deposits. Boxwork is typically composed of calcite, but it can be made of many different minerals. It primarily develops from differential erosion between a network of resistant material and the surrounding rock, but it can also be created through other processes (Hill \& Forti, 1997, and references therein). The Frasassi boxwork was first reported by Galdenzi (1990), who initially identified it as protruding sheets of calcite based on morphology and a misleading field test with $\mathrm{HCl}$.

This research analyzes the distribution and characteristics of boxwork along with related morphologies and mineral deposits and provides a first tentative hypothesis on their development. For each studied feature, the elevation was determined with a hydraulic digital level, connected to a preexisting tachometric traverse, and standardized with respect to a height zero reference located in the main spring at the cave entrance. Mineralogical and isotopic analyses were conducted on the most significant samples. Analytical methods are described in the Supplementary file.

\section{GENERAL CAVE SETTING}

The Frasassi cave system $\left(43^{\circ} 24^{\prime} \mathrm{N}, 12^{\circ} 57 " \mathrm{E}\right)$ is located in the Sentino River gorge in Ancona Province, Marche, Italy (Fig. 1), and is one of the most studied hypogene caves in Italy (Galdenzi \& Jones, 2017, with references therein). Sulfuric acid speleogenesis is still active in the lower sulfidic passages.

The Frasassi caves consist mainly of sub-horizontal passages that are organized into superimposed, interconnected levels related to deepening of the river valley. The lower levels develop close to the local base level, and include two main levels at 225 and $250 \mathrm{~m}$ asl. Dissolution occurred in the shallow phreatic zone due to the oxidation of sulfide (Galdenzi, 1990). Patchy replacement gypsum as well as corrosion pockets from subsequent gypsum removal demonstrate the contribution of $\mathrm{H}_{2} \mathrm{~S}$ oxidation to subaerial corrosion above the paleo water table (Galdenzi, 1990; Galdenzi \& Maruoka, 2003).

The hydrology and chemistry of the cave water are well known (Galdenzi et al., 2008). Groundwater in the shallow phreatic zone is a mixture of meteoric bicarbonate water and rising mineralized water. In many stagnant pools, groundwater stratification is common. The surface layer can vary from purely 


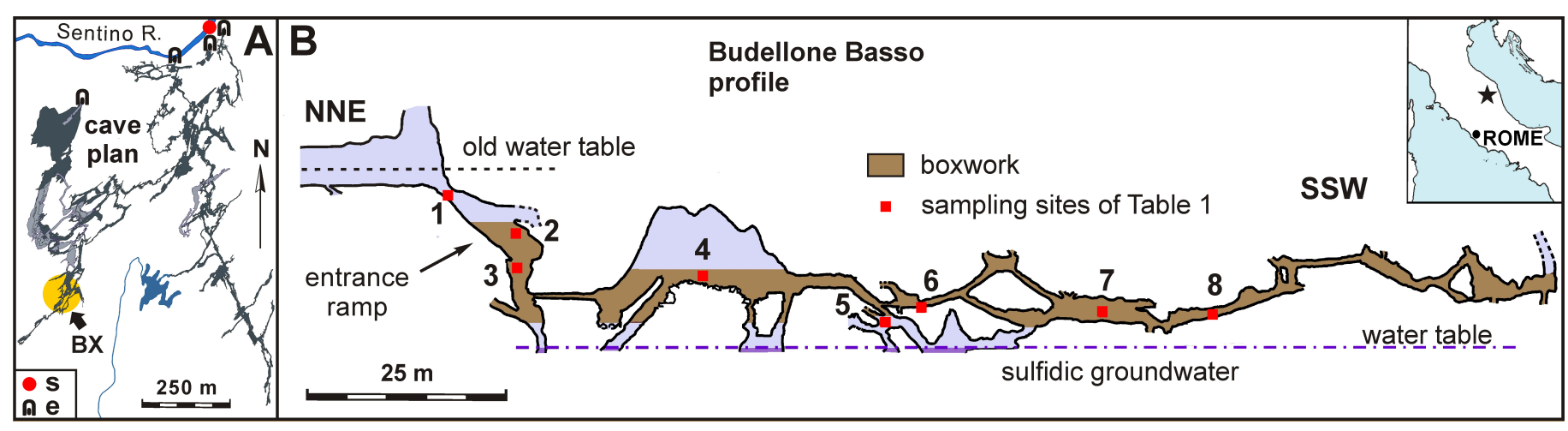

Fig. 1. A) Plan of the cave system, with location of the boxwork area (BX); s: sulfidic spring; e: cave entrance. B) Profile of the Budellone Basso di Sala della Neve, projected on the main trend of the passage (drawn based on the survey of E. Sbaffi \& G.G. Recanati).

bicarbonate to intermediate between seepage and mineralized water, typically with some dissolved $\mathrm{O}_{2}$ and without measurable $\mathrm{H}_{2} \mathrm{~S}$. The thickness of these surface layers ranges from a few $\mathrm{cm}$ to $5 \mathrm{~m}$ (Galdenzi et al., 2008). The sulfidic groundwater is cold (about $13^{\circ} \mathrm{C}$ ), and salinity (mainly sodium and chloride) approaches $2 \mathrm{gL}^{-1}$. The water also contains up to $20 \mathrm{mgL}^{-1}$ sulfide, up to $220 \mathrm{mgL}^{-1}$ sulfate and minor ions such as $\mathrm{Ba}^{2+}, \mathrm{Sr}^{2+}, \mathrm{Li}^{+}$, and $\mathrm{F}^{-}$, which are almost absent in the infiltration water. Dissolved salts likely originate in the underlying Triassic evaporitic formation (Anidridi di Burano), composed by alternation of dolostone, anhydrite and minor halite and known in the area only from deep wells (Anelli et al., 1994). The presence of barium in the sulfidic water was initially reported by Bertolani et al. (1977). Concentrations range from 0.11 to $0.19 \mathrm{mgL}^{-1}$ in samples collected in a variety of locations (Macalady, personal communication). Based on the measured ion concentration, the sulfidic water is oversaturated with barium sulfate. Oversaturation of barium sulfate is common in sulfidic groundwater in Central Italy (Baldi et al., 1973), with barium sourced by underlying Triassic evaporitic strata. In certain locations, rising sulfidic water produced economic barite-celestite deposits (Barbieri \& Masi, 1978).

\section{THE BOXWORK ZONE}

The studied boxwork is located in the Budellone Basso di Sala della Neve, a passage remote from the Sentino River in the southwestern sector of the cave (Fig. 1A). The Budellone is the main feeder to a large horizontal passage at $225 \mathrm{~m}$ asl, $26 \mathrm{~m}$ above the emergence of sulfidic water. Below the steeply inclined entrance the Budellone is a system of small, inclined or sub-horizontal, commonly anastomosing tubes. These passages have an irregular profile with many loops, and original phreatic features are excellently preserved (Fig. 1B). Deposits of subaerial replacement gypsum are lacking, with only a few remains found at the top of the entrance ramp. Aluminosilicate-rich clay deposits, which are widespread in the rest of the cave, are absent in this zone. Dripstone and vadose speleothems are also rare, in contrast to the rest of the cave, as this zone underlies a marly unit and receives little percolating water. Inside the Budellone, the water table can be reached in many places at 2.5 $\mathrm{m}$ above the spring, generally at the bottom of steeply dipping passages. A layer of oxygen-rich bicarbonate water floats above the sulfidic water, with a thickness that can range from a few to tens of centimetres. This thin bicarbonate layer prevents the release of $\mathrm{H}_{2} \mathrm{~S}$ into the cave atmosphere.

Widespread boxwork highlights the well-developed network of veins and pores filled by spar in the limestone (Fig. 2A, B). The boxwork generally protrudes several centimeters from the walls, exceeding $10 \mathrm{~cm}$ in a few places. It is composed of barite that replaced the original calcite spar. Cross sections of rock samples verified that only the portion of the veins that protrudes from the wall surface is replaced by barite, leaving the veins in the bedrock unaltered. The boxwork is commonly covered by a thin carbonate coating and generally has a reddish or brownish colour.

The boxwork zone is characterized by many different types of corrosional rills and channels that formed on the walls and ceilings by ascending fluids, likely water, that moved upward due to their lower density.

Most of the rills are a few millimeters wide and deep and extend for several decimeters. They begin either from half-cupolas or directly from injection points on the cave walls (Fig. 2C, D). Larger channels emerge from minor passages or niches in the walls. These channels can be over 10 centimeters wide and several centimeters deep. Their sections are generally rectangular, with clean, flat upper surfaces and steep, sub-vertical walls (Fig. 2E). Some of these wall channels reach the passage ceiling where they become inclined roof channels.

Incision of the rills and wall channels coincided with boxwork growth, as demonstrated by the presence of boxwork inside the niches and in some channels. On the ceilings, small flat cupolas likely represent former air bells that were rich in acidic gases $\left(\mathrm{H}_{2} \mathrm{~S}\right.$ and $\left.\mathrm{CO}_{2}\right)$ capable of contributing to the dissolution.

In most passages, the floor is covered by a thin layer of whitish mud that is weakly cohesive, is $94.5-97.5 \%$ carbonate composition and is commonly cracked by shrinkage structures. Detached boxwork lies on the whitish mud on the floor, indicating that the mud was deposited before the boxwork collapsed. White calcite rafts are abundant in places, hence the name of the cave passage ('neve' is Italian for snow). Rafts form small masses on the floor and walls and can overlie the boxwork.

Boxwork formed up to $15 \mathrm{~m}$ above the spring level, but an upper limit of distribution on the cave walls 

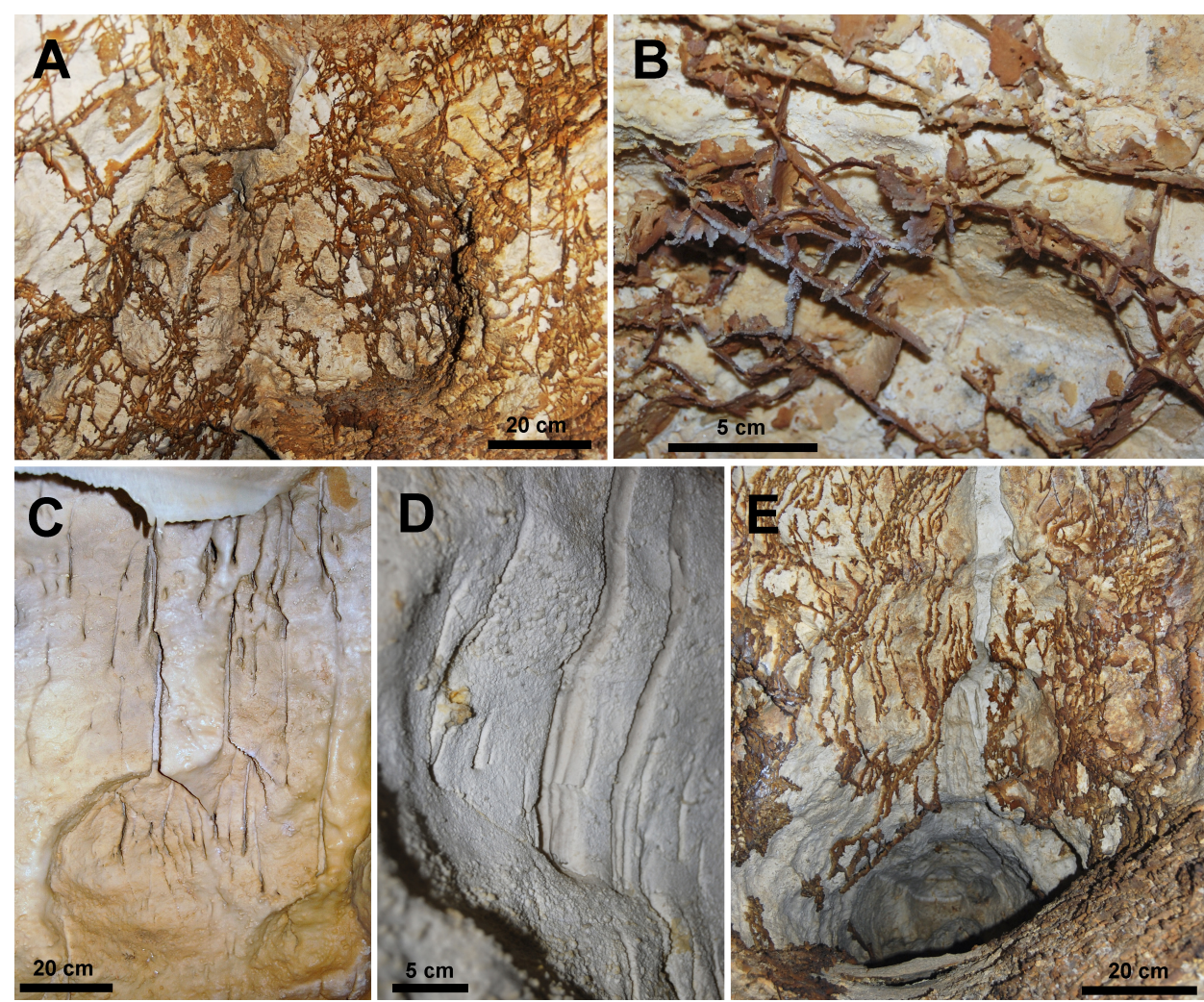

Fig. 2. A) General view of a cave wall covered by boxwork; B) Detail of boxwork; C) Ascending corrosion rills from a half-cupola; D) Details of rills from injection points; E) Co-existence of boxwork and an ascending channel rising from a tributary passage.

cannot be clearly defined. Below this height, wall features record changes that occurred during or after boxwork formation. The walls may be bare at different heights due to the destruction or detachment of the boxwork, and corrosional notches may mark previous chemoclines between different bodies of water. Subaqueous calcitic coatings are common at various heights and encrust the boxwork (Fig. 3A). These depositional events must have co-existed or alternated with corrosion by ascending fluids, as corrosion rills commonly incise calcite coatings on boxwork (Fig. $3 \mathrm{~B}, \mathrm{C})$. The vertical distribution of these horizontal
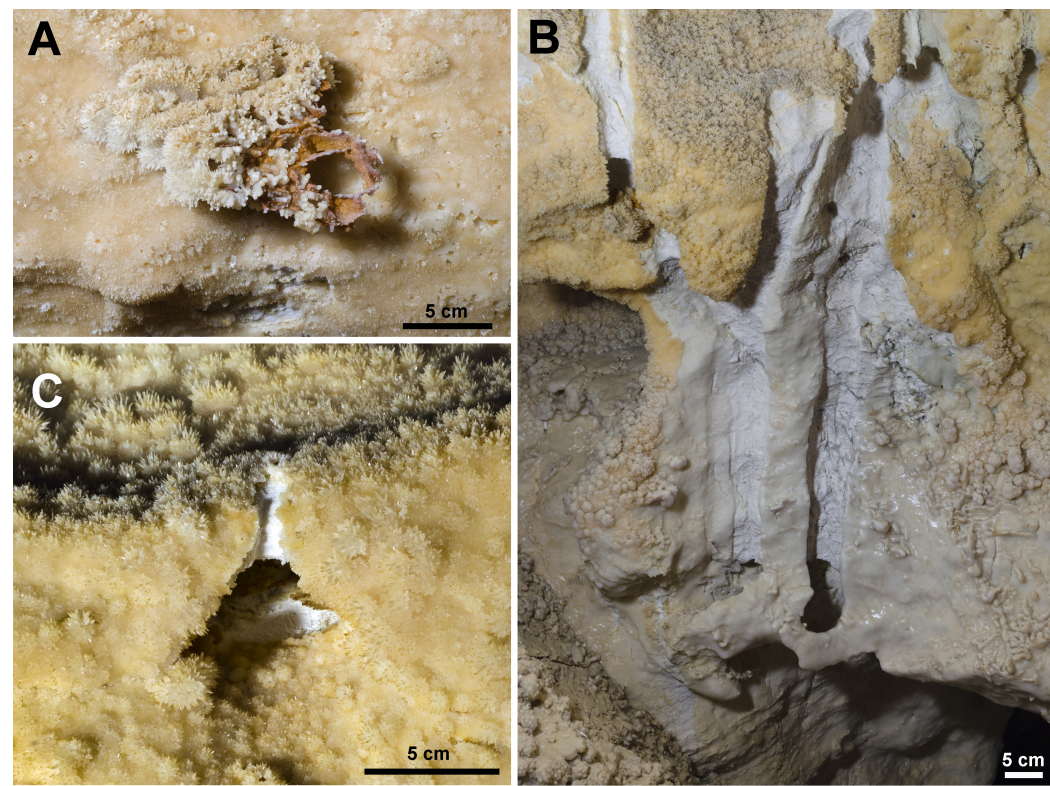

Fig. 3. Co-existence of depositional and corrosional features. A) Coating of subaqueous calcite crystals over the boxwork; B) Ascending channels carved in bedrock and calcite coating; note the hole in the rock created by the channel; C) Detail of the calcite coating corroded by a rill from an injection point. (Photos by A. Gianangeli). paleolevels is strongly influenced by local conditions, and in most examples, they do not extend into nearby passages.

\section{GEOCHEMISTRY}

\section{Carbonates}

The isotopic composition of the inorganic carbon in the cave water was monitored from 2008-2010 (unpublished data). The average $\delta^{13} \mathrm{C}$ value was $-10.5 \%$ or the seepage water, $-8.9 \%$ o for the sulfidic groundwater, and $-8.6 \%$ or the less diluted sulfidic water rising from the aquifer's deep zones. The $\delta^{13} \mathrm{C}$ of bicarbonate water at the surface of stratified lakes varied from $-7.8 \%$ o to $-5.6 \%$. Detailed measurements from a stalagmite revealed that the $\delta^{13} \mathrm{C}$ values ranged between -10 and $-5 \%$ o during the last $13 \mathrm{ka}$ (Tuccimei et al., 2003). A similar range of $\delta^{13} \mathrm{C}$ values was obtained from scattered samples of dripstones. In the limestone bedrock, the $\delta^{13} \mathrm{C}$ values were about $+2 \%$. All the samples from the boxwork study area had high $\delta^{13} \mathrm{C}$ values, compared to cave water and calcite speleothems (Table 1). The whitish carbonate mud on the floor and the limestone bedrock had similar $\delta^{13} \mathrm{C}$ values. The $\delta^{13} \mathrm{C}$ values of calcite rafts and crystals on the floors and walls ranged between -1.4 and $-4.8 \%$.

\section{Sulfur}

The $\delta^{34} \mathrm{~S}$ measured in barite samples ranged between +15.3 and $+17.3 \%$ o (Table 1 ). These values can be compared to those of the sulfur species dissolved in the sulfidic groundwater 
(Galdenzi \& Maruoka, 2003; unpublished data of 2008-2010 monitoring). In the water, the $\delta^{34} \mathrm{~S}$ varied between -18 and $-13 \%$ for dissolved sulfide and between +19 and $+22 \%$ o for dissolved sulfate. Sulfate $\delta^{34} \mathrm{~S}$ values decreased up to $+13 \%$ o during periods of high freshwater dilution.

Table 1. Isotopic composition of the cave samples. In brackets the sampling sites of Fig. 1.

\begin{tabular}{|c|c|c|c|}
\hline Calcite samples & & $\begin{array}{c}\delta^{13} \mathbf{C} \\
\% \text { PDB }\end{array}$ & $\begin{array}{c}\mathbf{\delta}^{18} \mathrm{O} \\
\% \text { SMOW }\end{array}$ \\
\hline B03 & limestone & -1.7 & -4.6 \\
\hline B22 (5) & spar vein & 0.9 & -5.7 \\
\hline B24 (7) & spar vein & 0.3 & -5.2 \\
\hline F57 (5) & whitish mud & 1.8 & -3.3 \\
\hline F62 (3) & whitish mud & 1.2 & -4.4 \\
\hline F58 (5) & raft & -1.4 & -7.1 \\
\hline F61 (6) & raft & -2.5 & -7.7 \\
\hline B21 (5) & wall paleolevel & -3.9 & -6.5 \\
\hline B23 (8) & crystals on boxwork & -2.9 & -6.9 \\
\hline F60 (7) & crystals on boxwork & -4.8 & -7.5 \\
\hline Barite samples & & \multicolumn{2}{|c|}{$\delta^{34} \mathrm{~S} \%$ V-CDT } \\
\hline B40 (7) & boxwork & \multicolumn{2}{|r|}{16.7} \\
\hline B48 (2) & boxwork & \multicolumn{2}{|c|}{16.6} \\
\hline B59 (7) & boxwork & \multicolumn{2}{|r|}{16.9} \\
\hline B62 (7) & boxwork & \multicolumn{2}{|r|}{15.7} \\
\hline B25 (4) & boxwork & \multicolumn{2}{|c|}{15.3} \\
\hline B39 (7) & boxwork & \multicolumn{2}{|r|}{16.4} \\
\hline $\mathrm{B} 53(6)$ & dark boxwork & \multicolumn{2}{|c|}{16.9} \\
\hline $\mathrm{B} 54$ (6) & reddish boxwork & \multicolumn{2}{|c|}{15.9} \\
\hline F59 (8) & boxwork & \multicolumn{2}{|r|}{16.6} \\
\hline F60 (8) & boxwork & \multicolumn{2}{|r|}{17.3} \\
\hline \multicolumn{4}{|l|}{ Gypsum samples } \\
\hline $\mathrm{B} 46(1)$ & replacement gypsum & \multicolumn{2}{|c|}{-16.9} \\
\hline B47 (1) & replacement gypsum & \multicolumn{2}{|c|}{-17.4} \\
\hline
\end{tabular}

\section{DISCUSSION}

Frasassi boxwork is distinct from boxwork found in other caves because it is not a simple product of differential corrosion between veins and the surrounding rock. It is the result of a specific cave process that coupled micrite corrosion and the replacement of calcite spar by barite. The barite replacement only affects the protruding parts of the calcite veins, and does not penetrate into the limestone, where the veins maintain their original composition.

Barite replacement boxwork occurs in a phreatic zone that fed a wide water table passage of the cave tier at $+26 \mathrm{~m}$ (Fig. 1B). It is a rare phenomenon in the cave system due to local conditions that did not occur anywhere else. Barite-replaced boxwork developed under subaqueous conditions when the passages had almost reached their final shape, in locations that probably were cut off from the cave atmosphere (Fig. 1B). These passages were still filled by sulfidic water, which was the source of barium and sulfate ions implicated in the replacement process (Fig. 4).
These bodies of sulfidic water were stagnant or had little movement, and water inflow from the walls produced limestone corrosion and a diffuse incision of ascending rills. The inflowing fluid likely was vadose bicarbonate water, which would have moved up the walls towards the groundwater surface due to its lower density. Bicarbonate water is derived from surface infiltration, and could have descended below groundwater level because of the hydraulic head in fissures inside the limestone.

The inflowing fluid generated the acidity responsible for the observed bedrock corrosion (Fig. 4). The oxygen carried from the surface by vadose water could have promoted the oxidation of $\mathrm{H}_{2} \mathrm{~S}$ to sulfuric acid, which is considered to be the main cave-forming process in the cave (Galdenzi, 1990), and is associated with the release of bicarbonate ions derived from limestone dissolution. The process was sufficiently slow to result in the complete removal of micrite, while spar was replaced by barite, setting into relief the network of fissures and pores.

The inflow of oxygenated, bicarbonate water could not directly produce barite precipitation. Barite is poorly soluble, but vadose water has a low sulfate content with only trace amounts of barium (Bertolani et al., 1977). Furthermore, barite solubility is only slightly affected by $\mathrm{pH}, \mathrm{Ca}^{2+}, \mathrm{Mg}^{2+}$, and $\mathrm{Sr}^{2+}$ (ZhenWu et al., 2016), and therefore the acidity produced by sulfide oxidation should not influence barite precipitation. Barite precipitation might have been induced by the release of sulfate ions in the oxidation process, which produced a local increase in the $\mathrm{SO}_{4}{ }^{2-}$ concentration sufficient to precipitate barite. However, it is important to note that sulfate derived from $\mathrm{H}_{2} \mathrm{~S}$ oxidation was not directly involved in the replacement process. Barite $\delta^{34} \mathrm{~S}$ values (+15.3 to $+17.3 \%$ ) are dramatically different from the negative values of

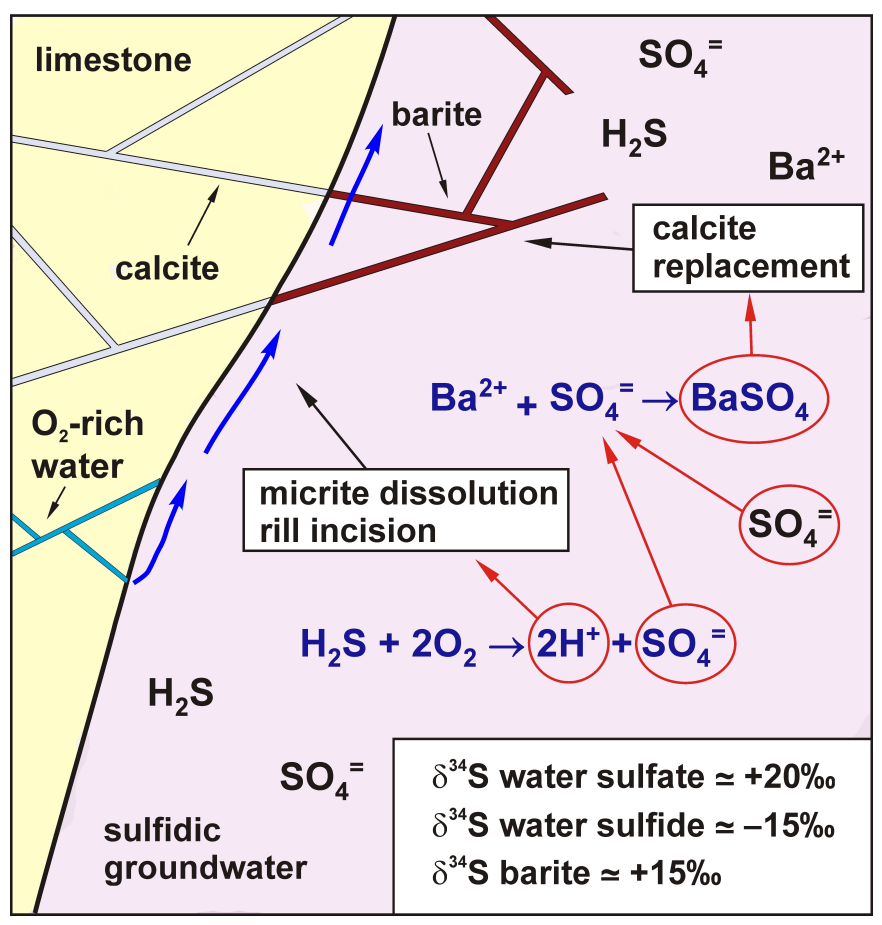

Fig. 4. Schematic model of the replacement process in sulfidic groundwater. Note that the $\delta^{34} S$ values of barite are less high than the present $\delta^{34} S$ of water sulfate, suggesting a contribution of sulfate ions produced by $\mathrm{H}_{2} \mathrm{~S}$ oxidation. 
dissolved sulfide $(-18$ to $-13 \%$ ) and are close to the present $\delta^{34} \mathrm{~S}$ of dissolved sulfate, which normally ranges between +19 and $+22 \%$. On the contrary the $\delta^{34} \mathrm{~S}$ barite values are compatible with an increase in dissolved sulfate due to $\mathrm{H}_{2} \mathrm{~S}$ oxidation.

After the main phase of boxwork growth, the water table progressively fell, until the whole zone was exposed to the cave atmosphere. This process was not continuous, because the groundwater level is dependent on erosion or sedimentation processes in the Sentino River valley. Changes in the elevation of the water table would have produced significant changes in the groundwater drainage in each passage.

The lowering of the water table facilitated gas exchange with the cave air, and the resulting $\mathrm{CO}_{2}$ degassing favored carbonate oversaturation in the groundwater. During this period, the boxwork was coated with subaqueous calcite, as indicated by crystalline coatings and overlying rafts. The carbon in these carbonate deposits has higher $\delta^{13} \mathrm{C}$ values than present cave waters, both sulphidic and vadose. It has values consistent with carbonate derived from limestone bedrock dissolution rather than atmospheric $\mathrm{CO}_{2}$ or decaying organic matter.

In the boxwork zone, the coexistence of corrosional rills and channels with calcite coatings and the evidence of crystal re-corrosion due to ascending water demonstrate that lateral freshwater recharge responsible for the corrosion was occurring. Alternating calcite corrosion and precipitation in the same passage was probably caused by changes in the elevation of the chemocline, amount of recharge, and also by variation of degassing towards the cave atmosphere. These processes resulted in boxwork that is well preserved over large areas, some coated with calcite and some not, at various elevations within the cave passages.

Close relationships between boxwork, corrosion rills and channels, and the process of calcite deposition/ corrosion in the same body of water highlight the complexity of the chemical processes involved in speleogenesis in the shallow phreatic zone at Frasassi.

\section{ACKNOWLEDGMENTS}

The present research developed by Gruppo Grotte Recanati and Gruppo Autonomo Speleologico Civitanova Marche was financed by Regione Marche in range of intervention for Speleology (L.R. 12/2000). I also wish to thank Margaret Palmer (State University of New York, Oneonta, USA) for diffractometric mineralogical analyses, Teruyuki Maruoka (University of Tsukuba, Japan) for the stable isotope analyses on the sulfur and carbon. I also thank Jennifer Macalady which helped to adapt the text, and the anonymous reviewers, whose useful comments helped to clarify some concepts and the text.

\section{REFERENCES}

Anelli L., Gorza M., Pieri M. \& Riva M., 1994 - Subsurface well data in the Northern Apennines (Italy). Memorie della Società Geologica Italiana, 48: 461-471.

Baldi P., Ferrara G.C., Masselli L. \& Pieretti G., 1973 Hydrogeochemistry of the region between Monte Amiata and Rome. Geothermics, 2 (3-4): 124-128.

https://doi.org/10.1016/0375-6505(73)90020-5

Barbieri M. \& Masi U., 1978 - Considerazioni geochimiche sull'origine del giacimento di barite e celestite di Pian dell'Organo (Civitavecchia). Rendiconti della Società Italiana di Mineralogia e Petrologia, 34: 161-166.

Bertolani M., Garuti G., Rossi A. \& Bertolani Marchetti M., 1977 - Motivi di interesse mineralogico e petrografico nel complesso carsico Grotta Grande del Vento-Grotta del Fiume. Le Grotte d'Italia, s. IV, 6: 109-144.

Galdenzi S., 1990 - Un modello genetico per la Grotta Grande del Vento. In: Galdenzi S. \& Menichetti M. (Eds.), Il carsismo della Gola di Frasassi. Memorie Istituto Italiano di Speleologia, s. II, 4: 123-142.

Galdenzi S., Cocchioni M., Morichetti L., Amici V. \& Scuri S., 2008 - Sulfidic ground-water chemistry in the Frasassi Caves, Italy. Journal of Cave and Karst Studies, 70 (2): 94-107.

Galdenzi S. \& Jones D.S., 2017 - The Frasassi caves: a "classical" active hypogenic cave. In: Klimchouk A.B., Palmer A.N., De Waele J., Auler A. \& Audra P., (Eds.), Hypogene karst regions and caves of the world. Springer, p. 143-159. https://doi.org/10.1007/978-3-319-53348-3 8

Galdenzi S. \& Maruoka T., 2003 - Gypsum deposits in the Frasassi Caves, central Italy. Journal of Cave and Karst Studies, 65 (2): 111-125.

Hill C.A. \& Forti P., 1997 - Cave minerals of the world $\left(2^{\text {nd }}\right.$ Ed.). National Speleological Society, Huntsville, 463 p.

Tuccimei P., Borsato A., Forti P., Frisia S., Paladini M., Piccini L., Salzano R. \& Sauro U., 2003 - Ricostruzione climatica dell'Olocene-Pleistocene superiore da una stalagmite del sistema carsico "Grotta del Fiume Grotta Grande del Vento" (Gola di Frasassi, Ancona, Italia). Studi Trentini Scienze Naturali, Acta Geologica, 80: 139-151.

Zhen-Wu B.Y., Dideriksen K., Olsson J., Raahauge P.J., Stipp S.L.S. \& Oelkers E.H., 2016 - Experimental determination of barite dissolution and precipitation rates as a function of temperature and aqueous fluid composition. Geochimica et Cosmochimica Acta, 194: 193-210.

https://doi.org/10.1016/j.gca.2016.08.041 


\section{METHODS}

\section{Analytical methods}

\section{Xray diffraction}

Xray diffraction of the boxwork samples was performed using a Rigaku Miniflex 200sc101 powder $\mathrm{X}$-ray diffractometer, $\mathrm{CuK}_{\mathrm{a}}$ radiation, $\mathrm{kV}=30, \mathrm{Ma}=$ 15 at Hartwick College, Oneonta, New York, U.S.A.

\section{Carbon-13 and Oxygen-18 analysis} of carbonate samples

The carbonate samples were analyzed in duplicate by Iso-Analytical Limited (United Kingdom). The average value is reported in delta notation. Two milligrams of fine dry powder of each sample was placed in clean glass septum capped vials. The vials were then sealed and their headspaces flushed with pure helium (99.995\%). After flushing, $\sim 0.5 \mathrm{~mL}$ of pure phosphoric acid, prepared according to Coplen et al. (1983), was injected into the vials and mixed with the sample powder. The samples were left to react for a period of not less than 36 hours to ensure complete conversion of carbonate to carbon dioxide for analysis. Standard reference materials were prepared in the same manner as the samples.

The $\mathrm{CO}_{2}$ gas was then analyzed by continuous flow isotope ratio mass spectrometry. The $\mathrm{CO}_{2}$ is flushed from the septum vial using a double holed needle and resolved on a packed column gas chromatograph. The carbon dioxide then enters the ion source of a Europa Scientific 20-20 IRMS and is ionized and accelerated. Here, gas species of different mass are separated in a magnetic field then simultaneously measured using a Faraday cup collector array at $\mathrm{m} / \mathrm{z} 44,45$, and 46.

The reference material used for this analysis was the laboratory's calcium carbonate standard IA-R022 $\left(\delta^{13} \mathrm{C}_{\mathrm{V}-\mathrm{PDB}}-28.63 \%\right.$ o and $\delta^{18} \mathrm{O}_{\mathrm{V}-\mathrm{PDB}}-22.69 \%$ o), which is traceable to NBS-19 Limestone $\left(\delta^{13} \mathrm{C}_{\mathrm{V} \text {-PDB }}+1.95 \%\right.$ o and $\delta^{18} \mathrm{O}_{\mathrm{V}-\mathrm{PDB}}-2.2 \%$ ). During analysis, NBS- 18 calcite $\left(\delta^{13} \mathrm{C}_{\mathrm{V}-\mathrm{PDB}}-5.00 \%\right.$ and $\delta^{18} \mathrm{O}_{\mathrm{V}-\mathrm{PDB}}-23.00 \%$ o $)$, NBS-
19 limestone and IA-R022 were analyzed as check samples.

\section{Sulphur-34 analysis of sulfate samples}

Sulfur isotopic compositions in cave samples were determined by a helium gas continuous flow isotope ratio mass spectrometer (CF-IR-MS; ISOPRIMEEA; Isoprime Ltd., UK) at the University of Tsukuba (Ikehata and Maruoka, 2016). The sulfur isotopic compositions are expressed in terms of $\delta^{34} \mathrm{~S}(\%)$ relative to the V-CDT (Vienna-Canyon-Diablo-Troilite) standard. The results of three IAEA (International Atomic Energy Agency) silver sulfide standards (IAEA-S- $1,-0.3 \%$; IAEA-S-2, +21.80\% ; IAEA-S-3, $-31.95 \%$; Mayer and Krouse, 2004) were compared to constrain the $\delta^{34} \mathrm{~S}$ values. The isotopic compositions of sulfur were determined to a precision of $\pm 0.1 \%$ o $(1 \sigma)$, the precision being reached by combining the standard deviations for repeated analyses of samples and standards (Maruoka et al., 2003).

\section{SUPPLEMENTARY REFERENCES}

Coplen T.B., Kendall C. \& Hopple J., 1983 - Comparison of stable isotope reference samples. Nature, 302: 236238. https://doi.org/10.1038/302236a0

Ikehata K. \& Maruoka T., 2016 - Sulfur isotopic characteristics of the volcanic products from the September 2014 Mount Ontake eruption, Japan. Earth Planets Space, 68: 116. https://doi.org/10.1186/s40623-016-0496-Z

Maruoka T., Koeberl C., Matsuda J. \& Syono Y., 2003 - Carbon isotope fractionation between graphite and diamond during shock experiments. Meteoritics and Planetary Science, 38: 1255-1262.

https://doi.org/10.1111/j.1945-5100.2003.tb00311.x

Mayer B. \& Krouse H.R., 2004 - Procedures for sulfur isotope abundance studies. In: de Groot P.A. (Ed.), Handbook of stable isotope analytical techniques. Elsevier, Amsterdam, 1, p. 538-596. https://doi.org/10.1016/B978-044451114-0/50028-4 